\title{
Epidemiological survey of human cytomegalovirus antibody levels in children from Southeastern China
}

Qi Zhang ${ }^{1,2,3}$, Yan Gao ${ }^{1,2,3}$, Ying Peng ${ }^{2,3,5}$, Miao Fu' ${ }^{4}$ Yan-Qing Liu ${ }^{1,2,3}$, Qiu-Ju Zhou ${ }^{1,2,3}$, Jian Yu ${ }^{1}$ and Xiao-Qun Zheng ${ }^{1,2,3^{*}}$

\begin{abstract}
Background: This study investigated infection status and distribution of human cytomegalovirus (HCMV) serum markers in hospitalized children from the Wenzhou region.

Methods: This survey was performed on 10,147 hospitalized children from birth to 14 years of age in Southeastern China (Wenzhou region) from March 2010 to March 2013. IgM and IgG antibodies to HCMV were quantitatively detected by chemiluminescence immunoassay (CLIA). HCMV IgM or IgG detection rates, concentration, and distribution in various age groups were retrospectively analyzed.

Results: In this study of hospitalized children, the overall rates of $\mathrm{HCMV} \mathrm{IgM}^{+}$and $\operatorname{lgG}^{+}$were $10.8 \%(1,099 / 10,147)$ and $83.0 \%(8,425 / 10,147)$, respectively. The lowest HCMV $\operatorname{lgM}^{+}$rate $(1.0 \%, P<0.001)$ was observed in the group of patients $<28$ days of age whereas the highest HCMV $\operatorname{lgM}^{+}$rate $(19.9 \%, P<0.001)$ occurred in the 28 days $\sim 5$ months old group. However, the concentrations of HCMV specific IgM in all age groups were not significantly different $(P>0.05)$. The $\mathrm{HCMV} \mathrm{IgG}^{+}$rate was highest in the $<28$ days group $(98.1 \%, P<0.001)$. The 28 days $\sim 5$ months old group had the lowest HCMV specific IgG concentrations (median, $133.9 \mathrm{AU} / \mathrm{mL}, P<0.001$ ). Among 1,099 HCMV $\operatorname{lgM}^{+}$children, 405 (36.9\%) were diagnosed with respiratory infections which pneumonia accounted for 18.2\% $(200 / 1,099)$ of the total population. However, children with respiratory infections had the lowest HCMV IgG concentrations (median, 161.1 AU/mL, $P<0.05$ ).
\end{abstract}

Conclusions: HCMV specific antibody responses are very common in hospitalized children with respiratory infection in Wenzhou region. Protection against HCMV airway infection needs greater emphasis and further studies will be helpful to reveal the role of HCMV in children respiratory disease.

Keywords: Human cytomegalovirus, Chemiluminescence immunoassay, Southeastern China, Child

\section{Introduction}

The $\beta$-herpesvirus, human cytomegalovirus (HCMV), is globally ubiquitous in the general population [1,2]. Its prevalence varies from $60-80 \%$ to $80-100 \%$ in developed and developing countries, respectively, depending on geography, ethnicity, and socio-economic conditions $[1,3]$. Prevalence tends to be high in South America, Africa, and Asia, but low in Western Europe and the United States [4].

\footnotetext{
* Correspondence: jszhengxq@163.com

'Department of Laboratory Medicine, The Second Affiliated Hospital \& Yuying Children's Hospital of Wenzhou Medical University, Wenzhou,

Zhejiang, China

${ }^{2}$ School of Laboratory Medicine, Wenzhou Medical University, Wenzhou, China

Full list of author information is available at the end of the article
}

HCMV can be transmitted to the fetus during the entire pregnancy period, and is the most frequent cause of congenital infections during pregnancy $[5,6]$. More than $10-15 \%$ of congenitally infected newborns have symptoms at birth, and 5-15\% of infected infants without symptoms will have adverse outcomes, including spontaneous abortion, neonatal death, or long-term neurologic sequelae (mental retardation, hearing loss, and visual impairment) [7-10]. Up to $60 \%$ of children are infected with HCMV in the first year of life with a wide range of clinical manifestations, such as pneumonia, infant hepatitis syndrome, and infectious mononucleosis. In older children, HCMV usually causes asymptomatic infections, although it may also be responsible for symptomatic 


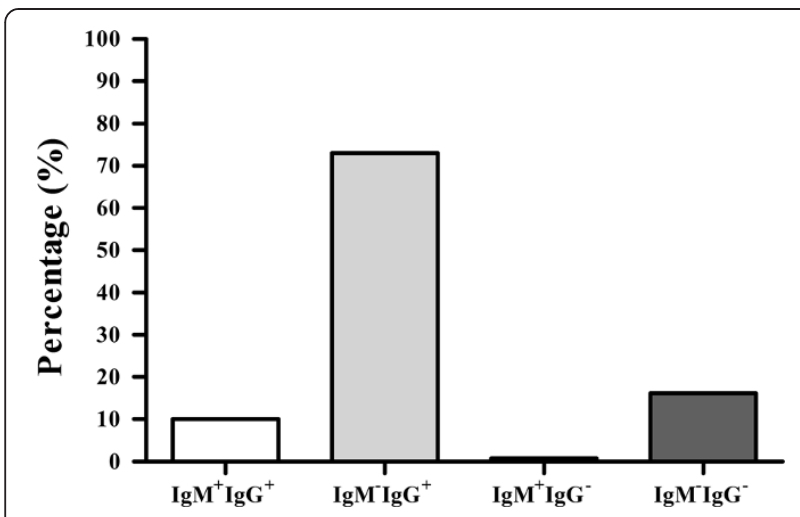

Figure 1 Serological results of HCMV antibodies in Wenzhou from 10,147 hospitalized children.

glandular fever and hepatitis [11]. Following primary infection, the virus may remain latent and later reactivate to cause recurrent infection under certain situations such as reinfection with other viral strains $[12,13]$.

However, data on HCMV infection prevalence in hospitalized children is scarce and most investigations have small sample sizes. Diagnosis of HCMV infection is mainly based on the HCMV specific IgG and IgM antibodies using enzyme-linked immunosorbent assay (ELISA) or chemiluminescence immunoassay in patient serum $[14,15]$. However, HCMV IgG and IgM couldn't be correctly quantified by ELISA because of the poor reproducibility of the ELISA tests [16]. This study determined HCMV infection prevalence in hospitalized children from the Wenzhou region by detecting anti-HCMV IgG and IgM accurately using the AxSYM CMV IgM and IgG chemiluminescence immunoassay in order to monitor early HCMV infection and diagnosis in hospitalized children.

\section{Results}

\section{HCMV seroprevalence}

Of 10,147 hospitalized children, the overall rate of HCMV infection was $83.7 \%(8,509 / 10,147)$. The rates of overall
$\operatorname{IgM}^{+}$and overall $\operatorname{IgG}^{+}$were $10.8 \%(1,099 / 10,147)$ and $83.0 \%(8,425 / 10,147)$, respectively. The rate of HCMV $\operatorname{IgM}^{+} \operatorname{IgG}^{+}$was $10.0 \%(1,015 / 10,147)$, the rate of $\mathrm{HCMV}$ $\operatorname{IgM}^{-} \operatorname{IgG}{ }^{+}$was $73.0 \%(7,410 / 10,147)$, the rate of $\mathrm{HCMV}$ $\operatorname{IgM}^{+} \operatorname{IgG}^{-}$was $0.8 \%(84 / 10,147)$, and the rate of $\mathrm{HCMV}$ IgM $^{-}$IgG $^{-}$was $16.1 \%(1,638 / 10,147)$ (Figure 1, Table 1).

\section{Detection of HCMV antibody in different age groups}

Differences in HCMV antibody levels among the 6 age groups were observed. (1) The $<28$ days group had the low-

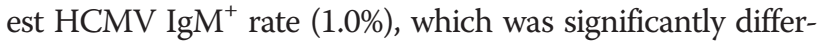
ent from the values for the other age groups $(P<0.001)$. (2) The HCMV $\operatorname{IgM}^{+}$rate $(19.9 \%)$ in the 28 days group was distinctly higher than the other groups $(P<0.001)$. (3) The highest $\mathrm{HCMV} \operatorname{IgG}^{+}$rate $(98.1 \%)$, observed in the $<28$ days group, was significantly different from the other groups $(P<0.001)$. (4) Infants younger than 12 months were excluded due to the potential for maternal HCMV-specific IgG $[17,18]$. Therefore, only groups aged $1-2$ years, 3-6 years, and 7-14 years were compared. The 7-14 years group had the highest $\mathrm{HCMV} \mathrm{IgG}^{+}$rate $(86.7 \%)$ among these three groups, a statistically significant difference $(P<0.001)$ (Table 1$)$.

\section{HCMV IgG concentration in seropositive individuals according to age}

There were no significant differences in HCMV IgM antibody concentration among the $<28$ days, 28 days5 months, $6-12$ months, $1-2$ years, $3-6$ years, and $7-14$ years groups $(P>0.05)$. A significant difference in HCMV IgG concentration was observed among these 6 groups $(P<0.01)$. The 28 days-5 months group (median: 133.9 AU/mL) had a significantly lower HCMV IgG level than the other groups $(P<0.001)$ (Table 2$)$.

\section{Disease distribution in $\mathrm{HCMV} \operatorname{lgM}^{+}$individuals}

The 1,099 $\mathrm{HCMV} \mathrm{IgM}^{+}$individuals had respiratory infections (36.9\%), hepatobiliary disease (17.7\%), and blood disorders (16.5\%) (Table 3). Viral DNA was

Table 1 Distribution of HCMV antibody results by age

\begin{tabular}{|c|c|c|c|c|c|c|c|}
\hline Age group & $\mathrm{N}$ & Overall $\operatorname{lgM}^{+}(\%)$ & Overall $\operatorname{lgG}^{+}(\%)$ & $\lg ^{+} \lg ^{-}(\%)$ & $\lg ^{+} \operatorname{lgG}^{+}(\%)$ & $\lg ^{-} \lg ^{+}(\%)$ & $\operatorname{lgM}^{-} \operatorname{lgG}^{-}(\%)$ \\
\hline$<28$ days & 1,137 & $11(1.0)$ & $1,114(98.1)$ & $1(0.1)$ & $10(0.9)$ & $1,104(97.2)$ & $22(1.9)$ \\
\hline 28 days & 3,205 & $639\left(19.9^{\mathrm{a}}\right)$ & $3,074\left(95.9^{c}\right)$ & $3(0.1)$ & $636(19.8)$ & 2,438 (76.1) & $128(4.0)$ \\
\hline 6 months & 1,828 & $115\left(6.3^{\mathrm{a} b}\right)$ & $1,342\left(73.4^{c}\right)$ & $16(0.9)$ & $99(5.4)$ & $1,243(68.0)$ & $470(25.7)$ \\
\hline 1 year & 1,755 & $168\left(9.6^{a b}\right)$ & $1,124\left(64.1^{c e}\right)$ & $36(2.1)$ & $132(7.5)$ & $992(56.5)$ & 595 (33.9) \\
\hline 3 years & 1,424 & $128\left(9.0^{a} \mathrm{~b}\right)$ & $1,079\left(75.8^{c} e^{c}\right)$ & $25(1.8)$ & $103(7.2)$ & $976(68.5)$ & $320(22.5)$ \\
\hline $7 \sim 14$ years & 798 & $38\left(4.8^{\mathrm{a} b}\right)$ & $692\left(86.7^{\circ}\right)$ & $3(0.4)$ & $35(4.4)$ & 657 (82.3) & $103(12.9)$ \\
\hline Total & 10,147 & $1,099(10.8)$ & $8,425(83.0)$ & $84(0.8)$ & $1,015(10.0)$ & $7,410(73.0)$ & $1,638(16.1)$ \\
\hline
\end{tabular}

Chi-square test.

${ }^{\text {a }} P<0.001$ compared to $<28$ days.

${ }^{\mathrm{b}} P<0.001$ compared to 28 days.

${ }^{c} P<0.001$ compared to $<28$ days.

${ }^{\mathrm{e}} \mathrm{P}<0.001$ compared to $7 \sim 14$ years. 
Table 2 HCMV IgG concentration in seropositive individuals by age group

\begin{tabular}{llll}
\hline Age & $\begin{array}{l}\text { HCMV-IgG } \\
\text { positive }\end{array}$ & $\begin{array}{l}\text { IgG concentration } \\
\text { (median, AU/mL) }\end{array}$ & $P$ \\
\hline$<28$ days & 1,114 & 248.1 & $<0.01^{*}$ \\
28 days & & & \\
6 months & 3,074 & 133.9 & $<0.01^{*}$ \\
1 year & 1,342 & 250 & $<0.01^{*}$ \\
3 years & 1,124 & 250 & $<0.01^{*}$ \\
$7 \sim$ 14 years & 1,079 & 194.2 & $<0.01^{*}$ \\
\hline
\end{tabular}

Note: ${ }^{\wedge}$ : 28-day group is significantly different from all other groups $(P<0.001$, Wilcoxon rank sum test).

*: there is a significant difference in HCMV IgG concentration distribution of these 6 groups $(P<0.01$, Kruskal-Wallis $\mathrm{H}$ test $)$

detected using real-time polymerase chain reaction (RT-PCR) of bronchoalveolar lavage (BAL) fluid from $58 \mathrm{HCMV} \mathrm{IgM}^{+}$with respiratory infections, of which 47 were positive by both IgM detection and RT-PCR whereas 11 cases were only IgM-positive (Table 4).

Table 3 Distribution of diseases in individuals positive for HCMV IgM

\begin{tabular}{|c|c|c|}
\hline Related diseases & $\begin{array}{l}\text { Age (median, } \\
\text { in months) }\end{array}$ & N (\%) \\
\hline Respiratory infections & $3(0-144)$ & $405(36.9)$ \\
\hline Pneumonia & $2(0-120)$ & $200(18.2)$ \\
\hline Bronchiolitis & $3(1-24)$ & $65(5.9)$ \\
\hline Upper respiratory tract infection & $10(1-144)$ & $52(4.8)$ \\
\hline Bronchopneumonia & $3(1-48)$ & $43(3.9)$ \\
\hline Blood disorders & $24(0-168)$ & $181(16.5)$ \\
\hline Thrombocytopenia & $3(0-120)$ & $69(6.3)$ \\
\hline Infectious mononucleosis & $48(4-168)$ & $68(6.2)$ \\
\hline Hepatobiliary disease & $2(0-144)$ & $194(17.7)$ \\
\hline Infant hepatitis syndrome & $2(1-12)$ & $95(8.6)$ \\
\hline Jaundice & $2(0-120)$ & $33(3.0)$ \\
\hline Gastrointestinal diseases & $3(1-48)$ & $79(7.2)$ \\
\hline Diarrhea & $3(1-12)$ & $41(3.7)$ \\
\hline Enteritis & $5(1-24)$ & $20(1.8)$ \\
\hline Infectious disease & $6(1-144)$ & $75(6.8)$ \\
\hline Septicemia & $2(1-36)$ & $29(2.6)$ \\
\hline Nervous system disease & $11(0-72)$ & $27(2.5)$ \\
\hline Convulsions & $8.5(1-72)$ & $18(1.6)$ \\
\hline Urinary system disease & $3(1-132)$ & $21(1.9)$ \\
\hline Urinary tract infection & $2(1-12)$ & $15(1.4)$ \\
\hline Fever of undetermined origin & $24(2-72)$ & $25(2.3)$ \\
\hline Other non-specific diseases & $4(0-168)$ & $92(8.4)$ \\
\hline Total & $4(0-168)$ & $1,099(100)$ \\
\hline
\end{tabular}

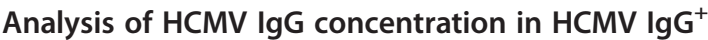 individuals according to disease}

HCMV IgG concentration was significantly lower in individuals with respiratory infections compared to other groups (median, 161.1 AU/mL, $P<0.05$ ). No significant differences were observed between the group with blood disorders, which had the highest HCMV IgG antibody concentration (median, 245.7 AU/mL, $P>0.05$ ), and other groups (Figure 2).

\section{Discussion}

In general, HCMV is acquired earlier in life among lower socioeconomic strata in developed countries and in developing countries [19]. In some African nations, HCMV seroprevalence is as high as $80-90 \%$ by 10 years of age; in contrast, seroprevalence is below $20 \%$ by 15 years of age among subgroups of children in the United States and Great Britain. Several studies have reported HCMV seropositivity rates in some parts of China. One study showed a more than $70 \%$ overall rate of HCMV infection among the children younger than 15 years old in the Shanghai area (Southeastern China) [20]. In Eastern China, several studies showed lower HCMV seroprevalence. Zhao et al. reported a 33.5\% HCMV seroprevalence in Jinan (Eastern China) among people younger than 20 years of age [21] and Sun et al. showed a $42.5 \%$ HCMV seroprevalence in people younger than 6 years old in the Weifang area (Eastern China) [22]. Our data show a $83.7 \%$ HCMV infection rate among hospitalized children in Wenzhou, higher than the study by Fang et al. , significantly higher than in Eastern China, indicating that HCMV is an important pathogen in hospitalized children of Southeastern China. The reasons for this high infection rate may be related to geography, socio-economic conditions, or sensitivity differences between testing methodologies.

Our data show that children less than 28 days of age had the highest HCMV $\operatorname{IgG}^{+}$and lowest HCMV $\operatorname{IgM}^{+}$ rates (Table 1). In addition, statistical analysis showed

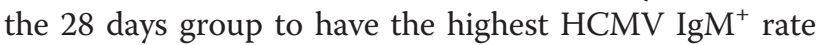
and the lowest HCMV IgG antibody concentrations. The reasons for these observations may include: (i) postnatal transmission of HCMV through breast milk [23-25]. HCMV is reactivated in latently infected mothers during lactation and breast-fed infants are susceptible to HCMV infection from breast milk, so infants are at risk for primary HCMV infection $[26,27]$. Because the infant cell-mediated and humoral immune system is immature, some infants (particularly $<28$ days of age) cannot produce an effective response to HCMV infections. (ii) The halflife of specific maternal IgG in infants is about 20 to 30 days $[28,29]$. As infants are exposed to external HCMV, maternal HCMV-specific IgG may be depleted to clear the virus. The HCMV IgG concentration in the 28 days age 
Table 4 PCR detection of BAL HCMV DNA from $58 \mathrm{HCMV} \mathrm{ggM}^{+}$individuals with different respiratory infections

\begin{tabular}{|c|c|c|c|c|}
\hline \multirow[t]{2}{*}{ Respiratory infections subcategories } & \multirow[t]{2}{*}{$\mathbf{N}$} & \multirow{2}{*}{$\begin{array}{l}\text { Mean age } \\
\text { (range months) }\end{array}$} & \multicolumn{2}{|c|}{ PCR detection results $(\mathrm{N})$} \\
\hline & & & Positive & Negative \\
\hline Pneumonia & 35 & $3.2(1-24)$ & 28 & 7 \\
\hline Bronchiolitis & 22 & $3.2(1-9)$ & 19 & 3 \\
\hline Upper respiratory tract infection & 1 & 24 & 0 & 1 \\
\hline Total & 58 & $3.6(1-24)$ & 47 & 11 \\
\hline
\end{tabular}

group was much lower than the high concentration observed in the <28 days age group, suggesting that the 28 days group may have increased risk of active HCMV infection (Table 2).

HCMV has a diverse tropism in its host and infects most types of cells, including epithelial and endothelial cells, fibroblasts, smooth muscle cells, and various hematopoietic cells [30]. During congenital infection, fetal lungs are particularly targeted by HCMV [31,32], leaving patients vulnerable to respiratory diseases, which account for $36.9 \%$ of all HCMV cases (Table 3). $\mathrm{HCMV} \operatorname{IgM}^{+}$individuals with respiratory infections showed that 11 of 58 cases were negative by Real-time PCR assay. The reason for this result may be that HCMV IgM was likely present, but the infection had been resolved. The liver is one of the most vulnerable organs infected by HCMV [33], and HCMV is the leading cause of infant hepatitis syndrome (IHS) [34]. In this

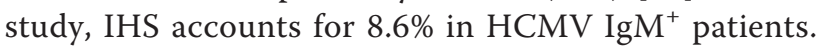
Although serological results suggest HCMV infection, further study is needed to distinguish whether HCMV infection and/or mixed infections with other pathogens results in these diseases.

\section{Conclusions}

In summary, this is the first study to our knowledge to screen for HCMV infection in hospitalized children in Wenzhou (Southeastern China). We observed a high HCMV prevalence rate of $83.7 \%$. Although no evidence was shown that HCMV was the cause of these respiratory infections, respiratory infection is a leading disease among hospitalized children positive for HCMV antibodies. The high prevalence of HCMV infection emphasizes HCMV diagnosis, prevention, and therapy for young children.

\section{Methods}

\section{Ethics statement}

This study was approved by the Ethics Committee of Wenzhou Medical University. Written informed consent was obtained for all study participants.

\section{Serum samples}

The serum samples used in this study were obtained from 10,147 children hospitalized at the Second Affiliated Hospital of Wenzhou Medical University between March 2010 and March 2013. The hospitalized children were classified into 6 sub-groups according age: 1-27 days,

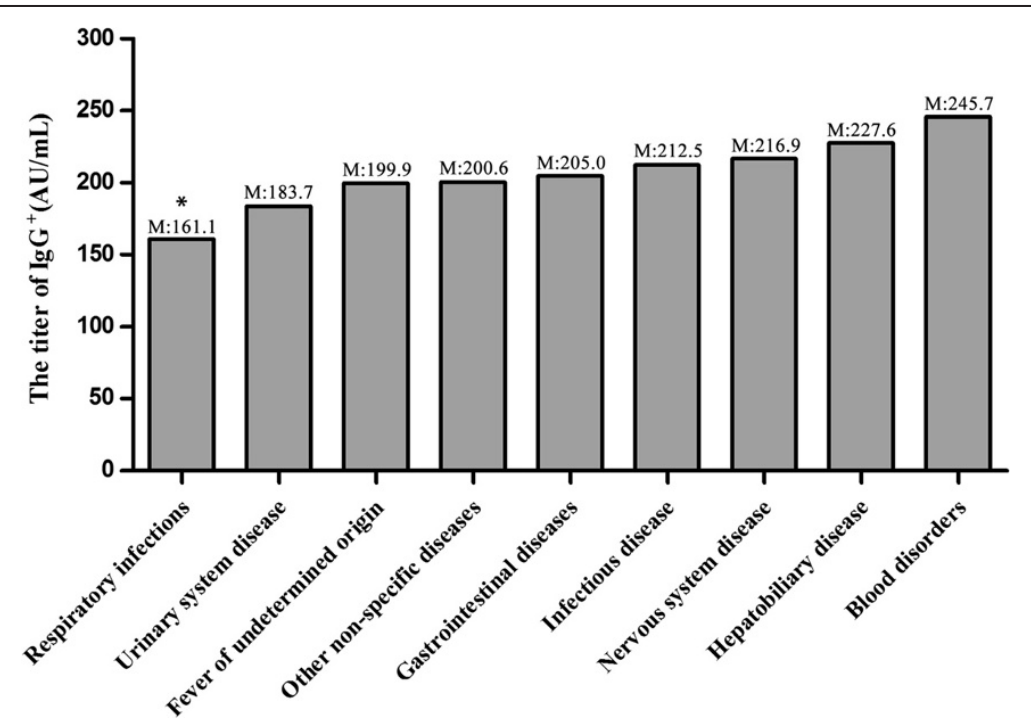

Figure 2 HCMV IgG concentration in HCMV IgG ${ }^{+}$individuals with system diseases. The group of patients with respiratory infections has the lowest HCMV IgG concentration, a statistically significant difference compared to the other groups (median, 161.1 AU/mL, P<0.05, Wilcoxon rank sum test). M represents the median HCMV IgG concentration within each group. 
28 days -5 months, $6-12$ months, $1-2$ years, $3-6$ years, and $7-14$ years.

\section{Bronchoalveolar lavage fluid samples for PCR detection of HCMV DNA}

Bronchoalveolar lavage (BAL) samples from $58 \mathrm{HCMV}$ $\mathrm{IgM}^{+}$individuals with respiratory infections (see Table 4 for detail information) were collected from pediatric patients with respiratory disease during their initial visits to their doctors. These 58 hospitalized patients were chosen for PCR detection of HCMV DNA from BAL because of their HCMV IgM positivity and clinical symptoms associated with HCMV infection. BAL were sampled using standard techniques, and the specimens were stored at $-80^{\circ} \mathrm{C}$ until RT-PCR was performed.

\section{Serology}

Patient blood samples were collected from the department of internal medicine. Two milliliters of whole blood from each patient were obtained and stored at $4{ }^{\circ} \mathrm{C}$ for 4 hours; serum was then separated by centrifugation at $4,000 \times \mathrm{rpm}$ for $10 \mathrm{~min}$ at $4^{\circ} \mathrm{C}$. Sera were frozen at $-20^{\circ} \mathrm{C}$ before measuring HCMV antibody concentrations. HCMV IgM and IgG were detected using a commercial microparticle chemiluminescence immunoassay (LIA) (AxSYM, Abbott Laboratories, USA) according to the manufacturer's instructions. Based on manufacturer's recommendations, HCMV-specific IgM index values $\geq 0.5$ and HCMV-specific IgG values $>15.00 \mathrm{AU} / \mathrm{mL}$ are considered positive, and the IgG upper limit is $250.00 \mathrm{AU} / \mathrm{mL}$.

\section{Quantitative PCR for HCMV DNA}

Nucleic acids $(50 \mu \mathrm{L})$ were extracted from $1 \mathrm{ml}$ BAL specimens. Two $\mu \mathrm{L}$ of the extracted DNA was subjected to each RT-PCR reaction using a commercially available Diagnostic kit for Quantification of Human Cytomegalovirus DNA (DAAN, China) following the manufacturer's instructions. RT-PCR assays were performed using the 7500 Real Time PCR System (Applied Biosystems, USA). HCMV DNA levels were reported as number of DNA copies per $\mathrm{ml}$ bronchoalveolar lavage fluid. The limit of detection of this quantitative assay is 500 copies $/ \mathrm{mL}$. The PCR condition is: initial denaturation step at $93^{\circ} \mathrm{C}$ for $2 \mathrm{~min}$, 10 cycles of denaturing at $93^{\circ} \mathrm{C}$ for $45 \mathrm{~s}$ and annealing and extension at $55^{\circ} \mathrm{C}$ for $1 \mathrm{~min}, 30$ cycles of denaturing at $93^{\circ} \mathrm{C}$ for $30 \mathrm{~s}$ and annealing and extension at $55^{\circ} \mathrm{C}$ for $45 \mathrm{~s}$.

\section{Statistical analysis}

The laboratory data were built into a Microsoft Excel database. Chi-squared, Kruskal-Wallis H, and Wilcoxon rank sum tests were performed to detect significant correlations between groups using SPSS Statistics for Windows, version 17.0 (SPSS, Inc., Chicago, IL, USA). $P<0.05$ was considered statistically significant.

\section{Abbreviations}

HCMV: Human cytomegalovirus; CLIA: Chemiluminescence immunoassay; BAL: Bronchoalveolar lavage; RT-PCR: Real-time polymerase chain reaction.

\section{Competing interests}

The authors declare that they have no competing interests.

\section{Authors' contributions}

$\mathrm{QZ}, \mathrm{YG}, \mathrm{YP}$ and $\mathrm{X}-\mathrm{QZ}$ conceived and designed the experiments. QZ, YG, and MF contributed to data collection and performed the experiments. QZ, Q-JZ, and YP participated in data and statistical analyses. QZ wrote the manuscript. $\mathrm{Y}-\mathrm{QL}, \mathrm{JY}$, and $\mathrm{YP}$ revised the manuscript. All authors read and approved the final manuscript.

\section{Acknowledgements}

We thank Dr. Haihua Gu for comments and critical reading of this manuscript. This project was supported by grants from the National Science Foundation of China (No. 81071365) and the Zhejiang Provincial Natural Science Foundation of China (NO. LY13H190006).

\section{Author details}

'Department of Laboratory Medicine, The Second Affiliated Hospital \& Yuying Children's Hospital of Wenzhou Medical University, Wenzhou, Zhejiang, China. ${ }^{2}$ School of Laboratory Medicine, Wenzhou Medical University, Wenzhou, China. ${ }^{3}$ Key Laboratory of Laboratory Medicine, Ministry of Education, Wenzhou, China. ${ }^{4}$ Department of Laboratory Medicine, Jinhua Municipal Central Hospital, Jinhua, Zhejiang, China. ${ }^{5}$ Present adress:

University of Missouri, Columbia, MO 65211, USA.

Received: 13 April 2014 Accepted: 30 June 2014

Published: 4 July 2014

\section{References}

1. Chen J, Hu L, Wu M, Zhong T, Zhou YH, Hu Y: Kinetics of IgG antibody to cytomegalovirus (CMV) after birth and seroprevalence of anti-CMV IgG in Chinese children. Virol J 2012, 9:304.

2. Lazzarotto T, Galli C, Pulvirenti R, Rescaldani R, Vezzo R, La Gioia A, Martinelli C, La Rocca S, Agresti G, Grillner L, Nordin M, Van Ranst M, Combs B, Maine GT, Landini MP: Evaluation of the Abbott AxSYM cytomegalovirus (CMV) immunoglobulin M (IgM) assay in conjunction with other CMV IgM tests and a CMV IgG avidity assay. Clin Diagn Lab Immunol 2001, 8:196-198.

3. De Paschale M, Agrappi C, Manco MT, Clerici P: Positive predictive value of anti-HCMV IgM as an index of primary infection. $J$ Virol Methods 2010, 168:121-125.

4. Swanson EC, Schleiss MR: Congenital cytomegalovirus infection: new prospects for prevention and therapy. Pediatr Clin North Am 2013, 60:335-349.

5. Doerr HW: Cytomegalovirus infection in pregnancy. J Virol Methods 1987, 17:127-132.

6. Cannon MJ, Davis KF: Washing our hands of the congenital cytomegalovirus disease epidemic. BMC Public Health 2005, 5:70.

7. Boppana SB, Pass RF, Britt WJ, Stagno S, Alford CA: Symptomatic congenital cytomegalovirus infection: neonatal morbidity and mortality. Pediatr Infect Dis J 1992, 11:93-99.

8. Conboy TJ, Pass RF, Stagno S, Alford CA, Myers GJ, Britt WJ, McCollister FP, Summers MN, MCFarland CE, Boll TJ: Early clinical manifestations and intellectual outcome in children with symptomatic congenital cytomegalovirus infection. J Pediatr 1987, 111:343-348.

9. Lazzarotto T, Varani S, Guerra B, Nicolosi A, Lanari M, Landini MP: Prenatal indicators of congenital cytomegalovirus infection. J Pediatr 2000, 137:90-95.

10. Yow MD, Williamson DW, Leeds $L$, Thompson P, Woodward RM, Walmus BF, Lester JW, Six HR, Griffiths PD: Epidemiologic characteristics of cytomegalovirus infection in mothers and their infants. Am J Obstet Gynecol 1988, 158:1189-1195.

11. Griffiths PD: Strategies to prevent CMV infection in the neonate. Semin Neonatol 2002, 7:293-299.

12. Boppana $S B$, Rivera $L B$, Fowler $K B$, Mach $M$, Britt WJ: Intrauterine transmission of cytomegalovirus to infants of women with preconceptional immunity. N Engl J Med 2001, 344:1366-1371. 
13. Burny W, Liesnard C, Donner C, Marchant A: Epidemiology, pathogenesis and prevention of congenital cytomegalovirus infection. Expert Rev Anti Infect Ther 2004, 2:881-894.

14. Revello MG, Gerna G: Diagnosis and management of human cytomegalovirus infection in the mother, fetus, and newborn infant. Clin Microbiol Rev 2002, 15:680-715.

15. Maine GT, Stricker R, Schuler M, Spesard J, Brojanac S, Iriarte B, Herwig K, Gramins T, Combs B, Wise J, Simmons H, Gram T, Lonze J, Ruzicki D, Byrne B, Clifton JD, Chovan LE, Wachta D, Holas C, Wang D, Wilson T, Tomazic-Allen S, Clements MA, Wright GL Jr, Lazzarotto T, Ripalti A, Landini MP: Development and clinical evaluation of a recombinant-antigen-based cytomegalovirus immunoglobulin $M$ automated immunoassay using the Abbott AxSYM analyzer. J Clin Microbiol 2000, 38:1476-1481.

16. Lazzarotto T, Dalla Casa B, Campisi B, Landini MP: Enzyme-linked immunoadsorbent assay for the detection of cytomegalovirus-IgM: comparison between eight commercial kits, immunofluorescence, and immunoblotting. J Clin Lab Anal 1992, 6:216-218.

17. Almeida LN, Azevedo RS, Amaku M, Massad E: Cytomegalovirus seroepidemiology in an urban community of Sao Paulo, Brazil. Rev Saude Publica 2001, 35:124-129.

18. Huang LM, Lee CY, Chang MH, Wang JD, Hsu CY: Primary infections of Epstein-Barr virus, cytomegalovirus, and human herpesvirus-6. Arch Dis Child 1993, 68:408-411.

19. Stagno S, Cloud GA: Changes in the epidemiology of cytomegalovirus. Adv Exp Med Biol 1990, 278:93-104.

20. Fang FQ, Fan QS, Yang ZJ, Peng YB, Zhang L, Mao KZ, Zhang Y, Ji YH: Incidence of cytomegalovirus infection in Shanghai, China. Clin Vaccine Immunol 2009, 16:1700-1703.

21. Zhao P, Ma DX, Xue FZ, Ji CY, Wang SK, Zhang XM, Zhou YB, Yu XP: Seroprevalence and risk factors of human cytomegalovirus infection in the eastern Chinese population. Arch Virol 2009, 154:561-564.

22. Sun XN, Liu ZJ, Wang B, Shi LH, Liang RW, Li L, Qian DM, Song XX: Sero-epidemiological survey of human cytomegalovirus-infected children in Weifang (Eastern China) between 2009 and 2012. Virol J 2013, 10:42.

23. Dworsky M, Yow M, Stagno S, Pass RF, Alford C: Cytomegalovirus infection of breast milk and transmission in infancy. Pediatrics 1983, 72:295-299.

24. Vochem M, Hamprecht K, Jahn G, Speer CP: Transmission of cytomegalovirus to preterm infants through breast milk. Pediatr Infect Dis J 1998, 17:53-58.

25. Stagno S, Reynolds DW, Pass RF, Alford CA: Breast milk and the risk of cytomegalovirus infection. N Engl J Med 1980, 302:1073-1076.

26. Meier J, Lienicke U, Tschirch E, Kruger DH, Wauer RR, Prosch S: Human cytomegalovirus reactivation during lactation and mother-to-child transmission in preterm infants. J Clin Microbiol 2005, 43:1318-1324.

27. Numazaki K: Human cytomegalovirus infection of breast milk. FEMS Immunol Med Microbiol 1997, 18:91-98.

28. Munoz FM, Piedra PA, Glezen WP: Safety and immunogenicity of respiratory syncytial virus purified fusion protein-2 vaccine in pregnant women. Vaccine 2003, 21:3465-3467.

29. Watanaveeradej $V$, Endy TP, Samakoses R, Kerdpanich A, Simasathien S, Polprasert N, Aree C, Vaughn DW, Ho C, Nisalak A: Transplacentally transferred maternal-infant antibodies to dengue virus. Am J Trop Med Hyg 2003, 69:123-128.

30. Sinzger C, Digel M, Jahn G: Cytomegalovirus cell tropism. Curr Top Microbiol Immunol 2008, 325:63-83.

31. Bissinger AL, Sinzger C, Kaiserling E, Jahn G: Human cytomegalovirus as a direct pathogen: correlation of multiorgan involvement and cell distribution with clinical and pathological findings in a case of congenital inclusion disease. J Med Virol 2002, 67:200-206.

32. Gabrielli L, Bonasoni MP, Lazzarotto T, Lega S, Santini D, Foschini MP, Guerra B, Baccolini F, Piccirilli G, Chiereghin A, Petrisli E, Gardini G, Lanari M, Landini MP: Histological findings in foetuses congenitally infected by cytomegalovirus. J Clin Virol 2009, 46(Suppl 4):S16-S21.
33. Jiwa NM, Raap AK, van de Rijke FM, Mulder A, Weening JJ, Zwaan FE, The $\mathrm{TH}$, van der Ploeg M: Detection of cytomegalovirus antigens and DNA in tissues fixed in formaldehyde. J Clin Pathol 1989, 42:749-754.

34. Liu Z, Tian Y, Wang B, Yan Z, Qian D, Ding S, Song X, Bai Z, Li L: Serum proteomics with SELDI-TOF-MS in congenital human cytomegalovirus hepatitis. J Med Virol 2007, 79:1500-1505.

doi:10.1186/1743-422X-11-123

Cite this article as: Zhang et al.: Epidemiological survey of human cytomegalovirus antibody levels in children from Southeastern China. Virology Journal 2014 11:123.

\section{Submit your next manuscript to BioMed Central and take full advantage of:}

- Convenient online submission

- Thorough peer review

- No space constraints or color figure charges

- Immediate publication on acceptance

- Inclusion in PubMed, CAS, Scopus and Google Scholar

- Research which is freely available for redistribution

Submit your manuscript at www.biomedcentral.com/submit
C) Biomed Central 